\title{
BIODIVERSITY OF WEEDS AND SOIL SEED BANK IN ORGANIC AND CONVENTIONAL FARMING SYSTEMS
}

\author{
Adam Kleofas Berbeć, Beata Feledyn-Szewczyk \\ Institute of Soil Science and Plant Cultivation, State Research Institute in Puławy, Poland \\ aberbec@iung.pulawy.pl
}

\begin{abstract}
The aim of the study was to compare weed species diversity in organic and conventional farms in Poland. The study was carried out between 2012 and 2014 on production fields located in Lublin province, one of the easternmost regions of Poland. The results showed that diversity and abundance of weeds in spring cereals were generally higher in organic farming system than in conventional one. No significant differences between systems were found in 2013, because local flooding of fields in spring made impossible the execution of agricultural weed management treatment for some farmers. Both above-ground and soil seed bank weed communities were the mainstay of valuable weed species, which is confirmed by the presence of the species threatened with extinction, for example, summer pheasant'seye (Adonis aestivalis), poorman's blue weatherglass (Anagallis foemina) and others in both tested farming systems. Dwarf everlast (Helichrysum arenarium) was the only found species that is subject to partial protection by Polish law. Both organic farms, run under CAP policy and support, and conventional extensive farms of the province of Lublin were the mainstay of biodiversity. Future rural development and CAP should be adapted and implemented regionally. Traditional extensive farms could contribute to the biodiversity and valuable plant species conservation.
\end{abstract}

Key words: biodiversity, weeds, farming systems, organic, conventional.

\section{Introduction}

Protection of biodiversity is one of the tasks of modern agriculture, which is reflected in the European Biodiversity Strategy (European Commission, 2011) that aims to halt the loss of biodiversity and ecosystem services in the EU by 2020. The abundance of animal and plant species is connected mostly with traditional extensive farming which is disappearing in modern, intensive agriculture of western Europe (Sutcliffe et al., 2015). Such traditional farms are also disappearing in most parts of Poland, but are still common in easternmost parts of the country. The biodiversity in traditional extensive farms can have a positive impact on environment and it can also be beneficial to farmers. Conservation of biodiversity is crucial for maintaining ecological services that provide soil fertility and productivity of agricultural ecosystems (Clergue et al., 2005). Biodiversity of rural areas is created mostly by the species and varieties richness of both cultivated and wild plants, but also by livestock and wild animals. It is well known that weeds have a negative impact on crop yields, mostly due to the competitiveness for all of environmental resources. Nowadays, it has become clear that weeds also play an important, positive role in the agricultural ecosystems. Those plants can create a number of various habitats for invertebrates. Pollinating insects and other insects that can provide biological pest control (e.g.: Carabidae, Hymenoptera, Orthoptera) are the examples of animals that live in the habitats created by weeds. Weeds are also a source of food for insects, small mammals; and also for farmland birds, which makes them important for the diversity of those groups of animals (Marshall et al., 2003). Conservation of biodiversity of arable lands could be beneficial to farmers. It can help farmers get more stable yields and lower cost of chemical protection against pests and diseases. Moreover, biodiversity of segetal flora (weeds) increases the aesthetic value of rural areas, which is important for agri-tourism.

Intensification of agriculture, mostly by simplified crop rotation, high amounts of chemical fertilizer and plant protection products, is the most important threat to the biodiversity of rural areas. Herbicides, widely used in conventional farming system, are the main reason of biodiversity decrease. The surface of unproductive areas like field margins, shrubs, midfield trees and ponds is often reduced to minimum in intensive conventional farming. Modern, sustainable agriculture should combine the production goals with environment protection. Farming system that uses environmentally friendly cultivation methods and protects biodiversity is organic farming (European Commission, 2007). Lubelskie region, due to its specific characteristics (fragmented agriculture, low input of plant protection products and mineral fertilizers, high biodiversity) is one of the regions that is especially predisposed to implement low-input production systems, for example, like organic farming. All of this makes he number of organic farms in the province of Lublin still increasing, and the area is ranked 5th in terms of the number of organic production farms (1896 farms) and 7th in terms of surface of organic production (29585 ha) (Salach \& Waszewska, 2016). Natural conditions of the province of Lublin favors the development of organic farming which produces food of high-quality but also has a positive impact on the environment, including biodiversity. The aim of the study was to compare weed species diversity in organic and conventional farms in Poland. 


\section{Materials and Methods}

The three-year study was carried out in 2012, 2013 and 2014 as a part of KIK/25 project: 'Protection of species diversity of valuable natural habitats on agricultural lands on Natura 2000 areas in the Lublin Voivodeship'. Research was carried out in Poland, in the province of Lublin, one of the easternmost regions of Poland. Study sites were located in the vicinity of NATURA 2000 areas.

At the beginning of the research, 14 organic and 14 conventional study squares of the area of 9 ha were selected. Organic study squares had at least $50 \%$ of organic agriculture surface share (run as certified organic agricultural fields), while conventional squares had at least $50 \%$ of conventional agriculture surface share (conventional - without organic certification). The chosen study squares had to be at least $500 \mathrm{~m}$ apart from forests and shelterbelts to minimize the impact of forests and woodlands on biodiversity samplings. Pairs of organic-conventional squares were located in the vicinity to each other, to keep their soil and climate conditions as similar as possible. In each square, a field of spring cereals - wheat (Triticum L.), barley (Hordeum L.) oats (Avena L.) or cereals and cereallegume mixtures - was located. Five test plots of the area of $0.5 \mathrm{~m}^{2}$ (spacing between plots $10 \mathrm{~m}$ ) were selected on each field. Above-ground weed species and their abundance were measured within every plot. Additionally, species found in the immediate vicinity of the test plots $\left(2 \mathrm{~m}^{2}\right)$ were also counted. Soil samples from the proximity of every test plot from $0-20 \mathrm{~cm}$ soil layer were taken in order to determine the species presence and their abundance in the soil seed bank, as well as to test soil parameters. Samples were placed in pots filled partially with sand (drainage) and placed in the greenhouse in order to evaluate seed species and their number present in the soil (ie. active seed bank). Exposure of soil seed bank lasted for 12 months. Both weed soil seed bank samples and above-ground evaluation took place annually, between 10th of June and 5th of July. The number of species, their abundance, as well as Shannon diversity index (H') (Shannon, 1948) and Simpson dominance index (SI) (Simpson, 1949) were counted to describe the biodiversity of weed communities. Shannon and Simpson indices were calculated using Past 3 software (Hammer, 2016). The statistical analysis was done on a basis of medians as most of variables had the distribution that was deviating from normal. A survey study with farm-holders was carried out to get knowledge about farms and agricultural practices performed on the tested fields. Weather conditions (precipitations and temperature) during the study period were similar to the long-term average for the region, with the exception of the year of 2013, in which rainfall in May was about twice as high as normal (Figure 1).

\section{Results and Discussion}

Characteristics of organic and conventional farms. The study squares and farms were randomly selected. The main features of the tested farms are given in Table 1. The tested organic and conventional farms differed significantly only on features linked with NPK fertilization, which was significantly higher in conventional farms, and the average grain yield which also was significantly higher in conventional farms $\left(3.0 \mathrm{t} \mathrm{ha}^{-1}\right)$ than in organic farms $\left(2.0 \mathrm{t} \mathrm{ha}^{-1}\right)$. Moreover, the tested farms had slightly larger farm areas than the regional average (average organic farms in Lublin region 18.5 ha, average conventional farms 38.5 ha; (GUS, 2016), which probably was a consequence of the study square selection criteria (at least $500 \mathrm{~m}$ away from the forest and other shelterbelts) which promoted larger fields. The tested organic farms relied mainly on the use of organic fertilizers

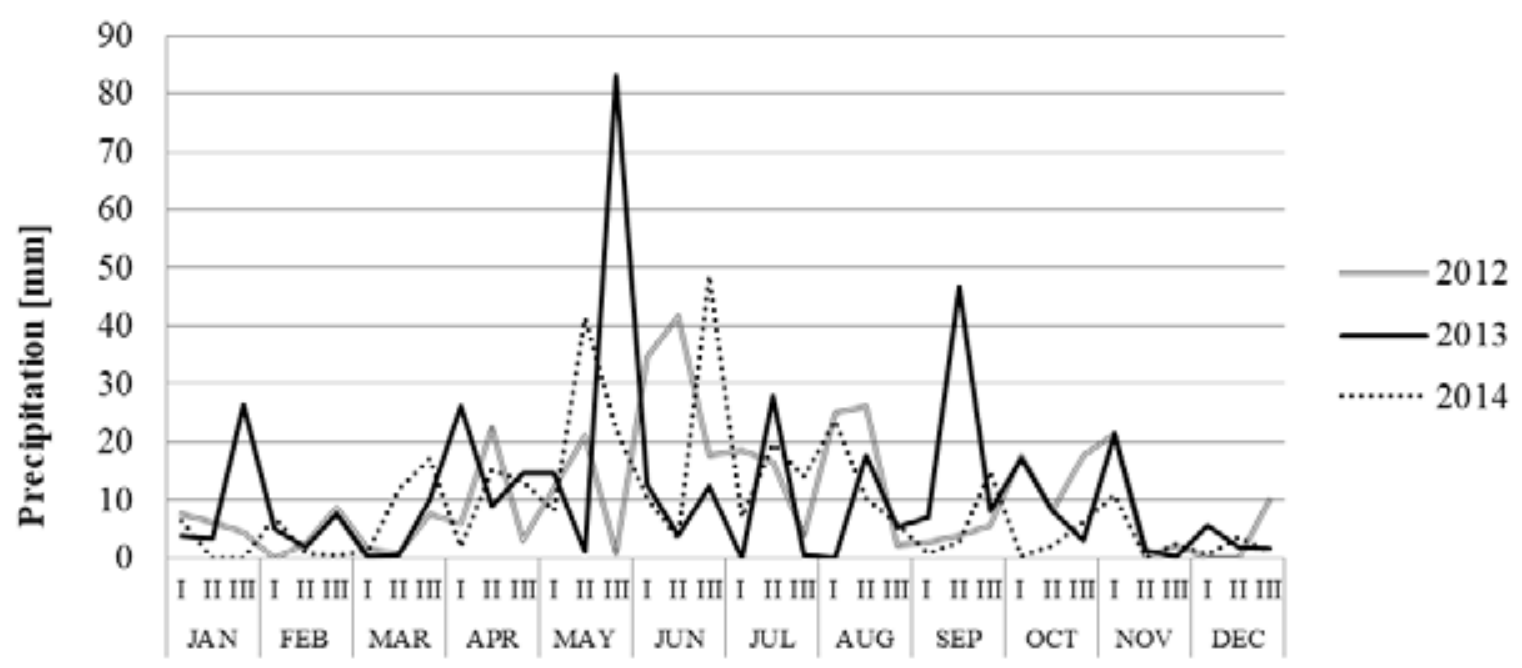

Figure 1. Precipitation (mm) in the study area during the study period (2012, 2013 and 2014). 
The main features of the tested organic (ORG) and conventional (CONV) farms

Table 1

\begin{tabular}{|c|c|c|}
\hline \multirow{2}{*}{ Feature } & \multicolumn{2}{|c|}{ Median } \\
\hline & ORG & CONV \\
\hline Area of the farm (ha) & $27.1^{\mathrm{a}}$ & $26.7^{\mathrm{a}}$ \\
\hline Soil class (I - best; VI - worse) & IV and $\mathrm{V}$ & IV and $\mathrm{V}$ \\
\hline $\mathrm{pH}$ in $\mathrm{KCl}$ & $4.57^{\mathrm{a}}$ & $4.93^{\mathrm{a}}$ \\
\hline Organic carbon (Corg) content $(\%)$ & $0.60^{\mathrm{a}}$ & $0.58^{\mathrm{a}}$ \\
\hline NPK mineral fertilization $\left(\mathrm{kg} \mathrm{ha}^{-1}\right)$ & $0^{\mathrm{a}}$ & $32^{\mathrm{b}}$ \\
\hline NPK organic fertilization $\left(\mathrm{kg} \mathrm{ha}^{-1}\right)$ & $0^{\mathrm{a}}$ & $36^{\mathrm{b}}$ \\
\hline SUM of NPK $\left(\mathrm{kg} \mathrm{ha}^{-1}\right)$ & $0^{\mathrm{a}}$ & $120^{\mathrm{b}}$ \\
\hline Number of harrowing (mechanical weed control) & $1^{\mathrm{a}}$ & $1^{\mathrm{a}}$ \\
\hline Number of sprayings with Plant Protection Products & $0^{\mathrm{a}}$ & $1^{\mathrm{a}}$ \\
\hline Share of fields with herbicide use (\%) & $0^{\mathrm{a}}$ & $70^{\mathrm{a}}$ \\
\hline Share of fields with use of PPPs other than herbicides (\%) & $0^{\mathrm{a}}$ & $10^{\mathrm{a}}$ \\
\hline Average yields of cereal grains $\left(\mathrm{t} \mathrm{ha}^{-1}\right)$ & $2.0^{\mathrm{a}}$ & $3.0^{\mathrm{b}}$ \\
\hline
\end{tabular}

${ }^{\mathrm{a}, \mathrm{b}}$ different letters in same row indicate significant differences between farming systems $(\mathrm{p}<0.05)$.

or catch crops as they used no mineral fertilizers, while conventional farms used minimal amounts of mineral fertilizers (Table 1). The number of harrowing was the same in both groups of farms. Conventional farms used low amounts of Plant Protection Products. Mechanical weed control (harrowing) was carried out only once a year in both farming systems (Table 1).

Above-ground weed species community and their abundance. There were 151 weed species found in total in spring cereals during the studies. Significantly more (131) weed species occurred in the organic farming system than in conventional farming system (116) (Table 2). Thirty-five species occurred only in organic farming system while next 20 - only in conventional farming system. Ninety-six species $(63 \%)$ were common for both farming systems. The study showed a larger number of species and their abundance in organic than in conventional farming system in two of three years of the study (Table 2 ). There were no significant differences between the farming systems only in 2013, when weather conditions were unfavourable and made weed control impossible for some farmers (local inundations of fields). Biodiversity of weeds in organic farming system is usually greater than in other intensive farming systems, which is well described in the literature (Edesi et al., 2012; Berbeć et al., 2013; Jastrzębska et al., 2013; Tuck et al., 2014; Kolářová, Tyšer, \& Soukup, 2015). Feledyn-Szewczyk and Duer (2007) found on average 17 species of weeds in organic spring wheat and 29 in organic spring barley, while in conventional farming the number of species was significantly lower (12 and 18 , respectively). The abundance of weeds in the presented study was significantly greater in organic than in conventional farming system. This dependence was confirmed by other authors (Feledyn-Szewczyk \& Duer, 2007; Koocheki et al., 2009; Edesi et al., 2012; Salonen et al., 2013), whooften found the weed infestation of organic cereals many times higher than conventional. Feledyn-Szewczyk (2012) found, on average, from 78 to $116 \mathrm{pcs} \mathrm{m}^{-2}$ of weeds in organic spring wheat while in conventional spring wheat there was only between 13 to 48 pcs $\mathrm{m}^{-2}$ of weeds depending on the year of the study. In the presented study, the differences between farming systems were not so large, but the infestation rate of spring cereals was generally greater (198-398 pcs $\left.\mathrm{m}^{-2}\right)$ in organic spring cereals than in conventional spring cereals $\left(65-258 \mathrm{pcs} \mathrm{m}^{-2}\right)$. Greater infestation rate of weeds was most likely due to the extensive crop production on farms, both organic and conventional. The relatively high abundance of weeds in the conventional farming system might be caused by the low efficacy of the herbicides, which was the result from wrong selection, inappropriate application or inadequate weather conditions during the application. Skrzyczyńska and Rzymowska (2000) investigated weed infestation in organic and traditional extensive farms and found that weed infestation was significantly greater in organic farming system.

Soil seed bank weed communities and their abundance. During the study, a total of 96 species of weeds were found in soil seed bank weed community. Significantly more species were found in organic (83) than in conventional farming system (78) (Table 3). Eighteen species were found only in organic farming system, while other 13 only in conventional farming system. The number of species in soil seed bank was 
Number and abundance of above-ground weed species in spring cereals in organic (ORG) and conventional (CONV) farming systems in the years $2012-2014$

\begin{tabular}{|l|c|c|}
\hline \multicolumn{1}{|c|}{ Parameters } & ORG & CONV \\
\hline Total number of species in above-ground weed communities & $131^{\mathrm{a}}$ & $116^{\mathrm{b}}$ \\
\hline Species unique for system & 35 & 20 \\
\hline \multicolumn{2}{|c|}{ Median of number of weed species per field } & $10^{\mathrm{b}}$ \\
\hline 2012 & $19^{\mathrm{a}}$ & $22^{\mathrm{a}}$ \\
\hline 2013 & $28^{\mathrm{a}}$ & $18^{\mathrm{b}}$ \\
\hline 2014 & $30^{\mathrm{a}}$ & $65^{\mathrm{b}}$ \\
\hline \multicolumn{2}{|c|}{ Median of abundance of weed flora $\left(\mathrm{pcs} \cdot \mathrm{m}^{-2}\right)$} & $198^{\mathrm{a}}$ \\
\hline 2012 & $298^{\mathrm{a}}$ \\
\hline 2013 & $398^{\mathrm{a}}$ & $188^{\mathrm{b}}$ \\
\hline 2014 & & \\
\hline
\end{tabular}

a,b different letters in the same row indicate significant differences between the farming systems $(\mathrm{p}<0.05)$.

significantly greater in organic than in conventional farms in 2012 and 2014. The abundance of seeds in the soil seed bank was also significantly greater in organic than in conventional farming system in each year of the study (Table 3.) In 2013 there were no differences between two systems in the number of species. The reason behind that is the fact that soil seed bank is closely related to actual weed infestation. The scattering of seeds from the same phytocoenosis is the main source of their inflow to the soil (Murphy et al., 2006; Wortman et al., 2010). Since the weed infestation in 2013 was high (even in the conventional farming system), and soil samples were collected in June and July, most of weed species were able to produce seeds and deposit them in the soil seed bank. This had major impact on conventional farming system, as even species rarely found in soil seed bank were able to germinate, grow and release seeds and increase seed reserve in the soil. Weed population on arable lands consists mainly of seeds in the soil, which was confirmed by the presented study (usually several thousand seeds per $1 \mathrm{~m}^{2}$ in soil seed bank versus several hundred plants per $1 \mathrm{~m}^{2}$ in the above-ground weed communities in the most abundant cases). Soil seed bank is an important reservoir of segetal flora. Chemical weed control is the main reason of differences in weed infestations between organic and conventional farming systems. Herbicides limit the population of sensitive weeds, however they often do not have any limiting effect on species not sensitive to them (Graziani et al., 2012). Soil seed bank is also affected by crop rotations. Organic farming often

Table 3

Number of species and seeds in soil seed bank in spring cereals in organic (ORG) and conventional (CONV) farming systems in the years $2012-2014$

\begin{tabular}{|l|c|c|}
\hline \multicolumn{1}{|c|}{ Parameters } & ORG & CONV \\
\hline Total number of species (soil seed bank weed communities) & $83^{\mathrm{a}}$ & $78^{\mathrm{b}}$ \\
\hline Species unique for system & 18 & 13 \\
\hline \multicolumn{2}{|c|}{ Median of number of weed species per field } & $22^{\mathrm{a}}$ \\
\hline 2012 & $20^{\mathrm{a}}$ & $17^{\mathrm{a}}$ \\
\hline 2013 & $22^{\mathrm{a}}$ & $15^{\mathrm{b}}$ \\
\hline 2014 & \multicolumn{2}{c|}{$5,400^{\mathrm{b}}$} \\
\hline \multicolumn{2}{|c|}{ Median of number of weed seeds $\left(\mathrm{pcs} \cdot \mathrm{m}^{-2}\right)$} & $5,600^{\mathrm{b}}$ \\
\hline 2012 & $10,600^{\mathrm{a}}$ & $4,400^{\mathrm{b}}$ \\
\hline 2013 & $9,300^{\mathrm{a}}$ & $8,400^{\mathrm{a}}$ \\
\hline 2014 & & \\
\hline
\end{tabular}

a,b different letters in the same row indicate significant differences between farming systems $(\mathrm{p}<0.05)$. 
Values of Shannon diversity (H') and Simpson dominance (SI) indices for above-ground and soil seed bank weed communities in organic and conventional farming systems

\begin{tabular}{|c|c|c|c|}
\hline \multicolumn{2}{|c|}{ Farming system } & \multirow{2}{*}{ Organic } & \multirow{2}{*}{ Conventional } \\
\hline Year & index & & \\
\hline \multicolumn{4}{|c|}{ Above-ground biodiversity } \\
\hline \multirow[t]{2}{*}{2012} & Shannon (H') & $2.553^{\mathrm{a}}$ & $2.311^{\mathrm{b}}$ \\
\hline & Simpson (SI) & $0.165^{\mathrm{a}}$ & $0.182^{\mathrm{b}}$ \\
\hline \multirow[t]{2}{*}{2013} & Shannon (H') & $2.994^{\mathrm{a}}$ & $2.637^{\mathrm{b}}$ \\
\hline & Simpson (SI) & $0.133^{\mathrm{a}}$ & $0.181^{\mathrm{b}}$ \\
\hline \multirow[t]{2}{*}{2014} & Shannon (H') & $2.727^{\mathrm{a}}$ & $2.599^{\mathrm{b}}$ \\
\hline & Simpson (SI) & $0.166^{\mathrm{a}}$ & $0.160^{\mathrm{b}}$ \\
\hline \multicolumn{4}{|c|}{ Soil Seed Bank biodiversity } \\
\hline \multirow[t]{2}{*}{2012} & Shannon (H') & $3.036^{\mathrm{a}}$ & $2.546^{\mathrm{b}}$ \\
\hline & Simpson (SI) & $0.074^{\mathrm{a}}$ & $0.146^{\mathrm{b}}$ \\
\hline \multirow[t]{2}{*}{2013} & Shannon (H') & $2.845^{\mathrm{a}}$ & $2.676^{\mathrm{b}}$ \\
\hline & Simpson (SI) & $0.086^{\mathrm{a}}$ & $0.122^{\mathrm{b}}$ \\
\hline \multirow[t]{2}{*}{2014} & Shannon (H') & $3.169^{\mathrm{a}}$ & $3.080^{\mathrm{b}}$ \\
\hline & Simpson (SI) & $0.072^{\mathrm{a}}$ & $0.074^{\mathrm{a}}$ \\
\hline
\end{tabular}

${ }^{a, b}$ different letters in same row indicate significant differences between farming systems $(p<0.05)$.

has more complex crop rotation. Different crops are associated with different weed species, which enrich the soil seed bank.

Graziani et al. (2012) found that biodiversity of soil seed bank of weeds in organic farms is often similar to the biodiversity of seeds in traditional extensive farms. According to the authors, this is due to the 'integrated' (mechanical + chemical) weed control of low intensity performed in traditional farms. Weather conditions can also have a significant impact on the weed biodiversity. In the presented study, weather conditions in late spring of 2013 (heavy rains) resulted in local inundations of fields. This made performing of weed control practices impossible for some farmers, and thus greatly increased weed infestation and increased inflow of seeds to the soil. As a result, no differences between systems in 2013 in the number of species and abundance of weeds in above-ground weed communities were found. At the same time, soil seed bank was more stable and resistant to external disturbances (significant differences in abundance of seeds between these two tested farming systems were found).

Biodiversity assessment with Shannon diversity and Simpson dominance indices. Shannon diversity index (H') showed significantly higher values in organic than in conventional farming system both in above-ground and in soil seed bank weed communities in each year of the study. The values of Simpson dominance (SI) index were significantly lower in organic than in conventional farming system in each year of the study for the above-ground weed communities. In the soil seed bank, Simpson dominance index was significantly lower in 2012 and 2013, while in 2014 there were no differences between those two farming systems (Table 4).

Shannon diversity and Simpson dominance indices showed better condition of biodiversity in organic than in conventional farming system. Nevertheless, Shannon diversity index for aboveground and soil seed bank had high values not only in organic $\left(\mathrm{H}^{\prime}=2.6-3.2\right)$, but also in conventional farming system $\left(\mathrm{H}^{\prime}=2.3-3.1\right)$, which indicates an important role of traditional extensive farms in biodiversity conservation. Armengot et al. (2013) found that Shannon diversity index had high values in organic weed communities found in cereals $\left(\mathrm{H}^{\prime}=2.5\right)$, while its values for conventional farming system were lower $\left(H^{\prime}=1.5\right)$. Feledyn-Szewczyk \& Duer (2007) confirmed that conditions of biodiversity were the best in organic and integrated farming system, worse in conventional farming system, and the worst in the long-term monoculture. Moreover, the authors found that Simpson dominance index for above-ground weed communities in organic farming system was low (0.25), while in the conventional farming system its values were higher $(>0.25)$. In the presented study, Simpson dominance index was low in both farming systems, and even in the conventional farming system its values did not exceed 0.18 , which indicates that 


\section{Endangered weed species in organic and conventional spring cereals}

\begin{tabular}{|c|c|c|c|c|}
\hline \multirow{2}{*}{ Species name and endangerment category } & \multicolumn{2}{|c|}{ Above-ground } & \multicolumn{2}{|c|}{ Soil seed bank } \\
\hline & ORG & CONV & ORG & $\mathrm{CONV}$ \\
\hline 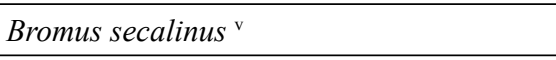 & $\times$ & - & - & - \\
\hline Ranunculus arvensis ${ }^{\mathrm{v}}$ & $x$ & $x$ & - & - \\
\hline Anagallis foemina $^{\mathrm{v}}$ & $x$ & $x$ & - & - \\
\hline Adonis aestivalis $^{\mathrm{v}}$ & - & $\times$ & - & - \\
\hline Myosurus minimus ${ }^{\mathrm{v}}$ & - & - & $x$ & $x$ \\
\hline${\text { Helichrysum } \text { arenarium }^{p}}^{p}$ & $x$ & $x$ & - & $x$ \\
\hline
\end{tabular}

$v$ - vulnerable according to Polish Red List of Plant and Fungi

$p$ - subject to partial legal protection in Poland

weed communities were not dominated by single species. Moreover, in the presented study Shannon diversity index for soil seed bank differentiated the two tested farming systems, but was high for both farming systems (2.55-3.17). Graziani et al. (2012) found that Shannon diversity index for soil seed bank was lower than 2.0 , and there were no significant differences between organic and conventional farms.

Endangered species. The presented study confirmed the positive impact of organic farming on biodiversity of weeds. It was also found that traditional extensive conventional farms, which are typical to eastern Poland, are of great importance in the protection of species diversity and, like organic farms, are the mainstay of valuable weed biodiversity. Confirmation of this is the fact that species enlisted in Red List of Plant and Fungi in Poland (Mirek, 2006) were found during the study in both organic and conventional farming systems. Those species included Ranunculus arvensis L., Anagallis foemina Mill. and Helichrysum arenarium (L.) Moench. Other endangered weed species, all marked as 'vulnerable', were found in organic or conventional farming systems (Table 5). Other rare species as Agrostema githago L., Veronica dillenii Crantz, Arnoseris minima L., Euphorbia exigua L., Geranium sanguineum L., Lathyrus tuberosus L., Campanula rapunculoides L. and Consolida regalis S.F. Gray were also found during the study. Helichrysum arenarium (L.) Moench was the only found species that is a subject to partial legal protection in Poland. Those species are disappearing under intensive conventional agriculture conditions but are still present in extensive farms of eastern Poland. The presence of rare and endangered species of segetal flora in both organic and conventional farms of eastern Poland is proof of the high environmental value of agro-ecosystems and the importance of organic and traditional extensive farming systems in biodiversity protection.

\section{Conclusions}

1. Studies have shown significantly higher species diversity and abundance of above-ground and soil seed bank weeds in organic than in conventional farms.

2. For both types of farms, the Shannon diversity index was higher for the soil seed bank than for above-ground flora, which indicates the importance of seeds in the soil as a reservoir of biodiversity.

3. Both organic and conventional farms of the province of Lublin are the mainstay of valuable segetal plant species, which is confirmed by the presence of the species threatened with extinction, as well as many other rare species.

4. The study showed that among the tested conventional farms there are also small family farms with low use of chemical inputs, which seems to be beneficial for weed biodiversity. Supporting such farms in further pro-ecological production seems necessary. Thus, rural development strategies and CAP should be adapted and implemented regionally to suit the local characteristics of agricultural production.

\section{Acknowledgements}

The study was conducted within KIK/25 project. The presented paper was developed within the 1.8 task of Multiannual Programme of Institute of Soil Science and Plant Cultivation, State Research Institute in Puławy, Poland.

\section{References}

1. Armengot, L., José-María, L., Chamorro, L., \& Sans, F.X. (2013). Weed harrowing in organically grown cereal crops avoids yield losses without reducing weed diversity. Agronomy for Sustainable Development, 33(2), 405-411. 
2. Berbeć, A.K., Radzikowski, P., Stalenga, J., Feledyn-Szewczyk, B., Hajdamowicz, I., \& Stańska, M. (2013). Ocena różnorodności flory segetalnej i owadów prostoskrzydłych w zbożach ozimych uprawianych w systemie ekologicznym i konwencjonalnym (An assessment of weed flora and orthopteran diversity in winter cereals cultivated in organic and conventional systems). Woda-Środowisko-Obszary Wiejskie, 13(4), 5-16. (in Polish).

3. Clergue, B., Amiaud, B., Pervanchon, F., Lasserre-Joulin, F., \& Plantureux, S. (2005). Biodiversity: function and assessment in agricultural areas. A review. Agronomy for Sustainable Development, 25(1): 1-15. DOI: 10.1051/agro: 2004049.

4. Edesi, L., Järvan, M., Adamson, A., Lauringson, E., \& Kuht, J. (2012). Weed species diversity and community composition in conventional and organic farming: a five-year experiment. Zemdirbyste=Agriculture, 99(4), 339-346.

5. European Commission. Council Regulation. (2007). Council Regulation (EC) No 834/2007 of 28 June 2007 on organic production and labelling of organic products and repealing. Regulation (EEC) No 2092/91. Official Journal of the European Union L 189. pp. 1-23.

6. European Commission. (2011). Communication From The Commission To The European Parliament, The Council, The Economic And Social Committee And The Committee Of The Regions Our Life Insurance, Our Natural Capital: An Eu Biodiversity Strategy To 2020. COM/2011/0244 final.

7. Feledyn-Szewczyk, B. (2012). The effectiveness of weed regulation methods in spring wheat cultivated in integrated, conventional and organic crop production systems. Journal of Plant Protection Research, 52(4), 486-493.

8. Feledyn-Szewczyk, B., \& Duer, I. (2007). Zachwaszczenie pszenicy jarej uprawianej w ekologicznym systemie produkcji w porównaniu $\mathrm{z}$ innymi systemami produkcji rolnej (Weed infestation in spring wheat cultivated in organic crop production system in comparison with other crop production systems). Journal of Research and Applications in Agricultural Engineering 52(3): 40-44. (in Polish).

9. Graziani, F., Onofri, A., Pannacci, E., Tei, F., \& Guiducci, M. (2012). Size and composition of weed seedbank in long-term organic and conventional low-input cropping systems. European Journal of Agronomy, 39, 52-61.

10. GUS (2016). Rocznik statystyczny rolnictwa (Statistical Yearbook). GUS, Warszawa ISSN 2080-8798 pp.165. (in Polish).

11. Hammer, Ø. (2016). PAST Paleontological Statistics Version 3.14: Reference Manual. Oslo.

12. Jastrzębska, M., Jastrzębski, W.P., Hołdyński, Cz., \& Kostrzewska, M.K. (2013). Weed species diversity in organic and integrated farming systems. Acta Agrobotanica 66(3), 113-124. DOI: 10.5586/aa.2013.045.

13. Kolářová, M., Tyšer, L., \& Soukup, J. (2015). Weed species diversity in the Czech Republic under different farming and site conditions. Acta Universitatis Agriculturae et Silviculturae Mendelianae Brunensis 63 (3), 741-749. DOI: 10.11118/actaun201563030741.

14. Koocheki, A., Nassiri, M., Alimoradi, L., \& Ghorbani, R. (2009). Effect of cropping systems and crop rotations on weeds. Agronomy for Sustainable Development 29(2), 401-408. DOI: 10.1051/agro/2008061.

15. Marshall, E.J.P., Brown, V.K., Boatman, N.D., Lutman, P.J.W., Squire, G.R., \& Ward, L.K. (2003). The role of weeds in supporting biological diversity within crop fields. Weed Research 43(2): 77-89. DOI: 10.1046/j.1365-3180.2003.00326.x.

16. Mirek, Z. (2006). Red list of plants and fungi in Poland. Władysław Szafer Institute of Botany, Polish Academy of Sciences. Kraków. ISBN: 83-89648-38-5.

17. Murphy, S.D., Clements, D.R., Belaoussoff, S., Kevan P.G., \& Swanton, C.J. (2006). Promotion of weed species diversity and reduction of weed seedbanks with conservation tillage and crop rotation. Weed Science 54(1), 69-77.

18. Salach, K., \& Waszewska, M. (2016). Wiedza i Jakość (Knowledge and Quality). Inspekcja Handlowej Jakości Artykułów Rolno-Spożywczych 2(43), 13-14. ISSN 1896-9569 pp.:13-14. (in Polish).

19. Salonen, J., Hyvönen, T., Kaseva, J., \& Jalli, H. (2013). Impact of changed cropping practices on weed occurrence in spring cereals in Finland-a comparison of surveys in 1997-1999 and 2007-2009. Weed Research, 53(2), 110-120.

20. Shannon, C.E.A. (1948). Mathematical theory of communications. Bell System Technical Journal, 27, 379-423.

21. Simpson, E.H. (1949). Measurement of diversity. Nature, 163, 688.

22. Skrzyczynska, J., \& Rzymowska, Z. (2000). Zachwaszczenie zbóż w gospodarstwach ekologicznych i tradycyjnych Podlasia Zachodniego (Changes in weed infestation of cereals in ecological and traditional farms of the Western Podlasie). Pamiętnik Puławski, 122, 51-58. (in Polish). 
23. Sutcliffe, L.M.E., Batary, P., Kormann, U., Baldi, A., Dics, L.V., Herzon, I., ... Tscharntke, T. (2015). Harnessing the biodiversity value of Central and Eastern European farmland. Diversity Distribution., 21: 722-730. DOI: 10.1111/ddi.12288.

24. Tuck, S.L., Winqvist, C., Mota, F., Ahnstrom, J., Turnbull, L.A., \& Bengtsson, J. (2014). Land-use intensity and the effects of organic farming on biodiversity: a hierarchical meta-analysis. Journal of Applied Ecology, 51, 746-755. DOI: 10,1111/1365-2664.12219.

25. Wortman, S.E., Lindquist, J.L., Haar, M.J., \& Francis, C.A. (2010). Increased weed diversity, density and above-ground biomass in long--term organic crop rotations. Renewable Agriculture and Food Systems, 25(04), 281-295. 